\title{
EFFECT OF GREEN TEA EXTRACT ON INJURED LIVER INDUCED BY ACETAAMINOPHEN IN RABBITS ADULT MALE
}

\author{
S. K.Mashi \\ Lecturer \\ saosanmashi@ymail.com
}

\section{ABSTRACT}

Dept. of Physiology and Pharmacology/Coll.Vet.Med.- Univ. of Baghdad

Green tea is consider as a natural sources of antioxidants used to treat pathological changes occurring as a result of using of many drugs particularly in the liver tissue. Forty adult male rabbits were randomly divided into four groups (10 rabbits /group) and were treated daily for $\mathbf{3 0}$ days as follows: first group (c): is the control group, second group $\left(T_{1}\right):$ rabbits in this group were allowed to ad libitum supply of drinking water containing $2.5 \mathrm{gm} / \mathrm{kg} \mathrm{b.w} \mathrm{of} \mathrm{green} \mathrm{tea} \mathrm{extract,} \mathrm{Third} \mathrm{group} \mathrm{(T2):}$ rabbits in this group received $500 \mathrm{mg} / \mathrm{kg} \mathrm{b.w.} \mathrm{of} \mathrm{acetaminophen} \mathrm{orally,} \mathrm{fourth} \mathrm{group}\left(\mathrm{T}_{3}\right)$ : rabbits in this group were allowed to ad libitum supply of drinking water containing $2.5 \mathrm{gm} / \mathrm{kg} \mathrm{b.w}$. of green tea extract and received $500 \mathrm{mg} / \mathrm{kg}$ b.w. of Acetaminophen orally. blood samples were collected for measuring the liver enzymes, cholesterol and triglyceride in blood serum at 15 and 30 days of experience. The results of this study revealed that oral intubation of acetaminophen for 30 days caused hepatic dysfunction manifested by a significant elevation $(P<0.05)$ in the serum AST,ALT ALP cholesterol and triglyceride while the animals received GTE with acetaminophen $\left(T_{3}\right)$ for 30 days showed a considerable decrease $(P<0.05)$ in serum AST, ALT,ALP, cholesterol and triglyceride levels. The histological section showed pathological changes in the liver tissue in (T2) group while giving green tea with acetaminophen was effective in modified these changes into semi normal.

Keywords : Green tea , acetaminophen, ALT, AST, ALP, cholesterol and triglyceride.

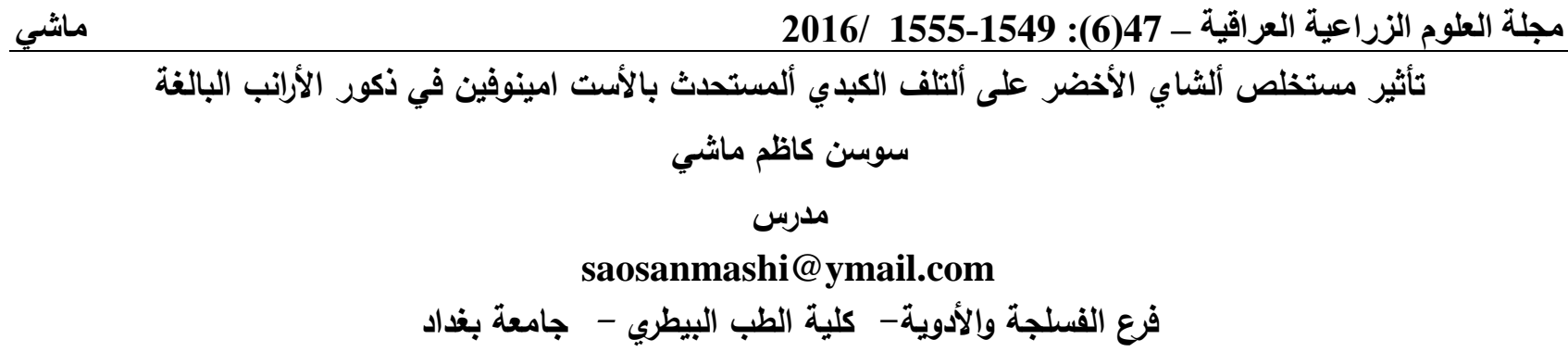

المستخلص

يعد الثاي الأخضرمن المصادر الطبيعة لمضادات الاكسدة المستخدمة لعلاج التغيرات المرضية الحاصلة نتيجة استخدا م العديد من

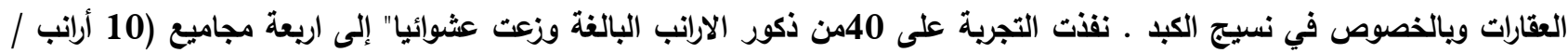

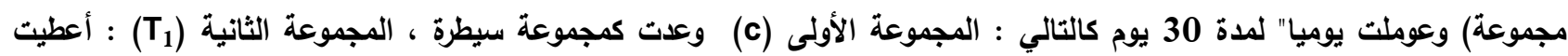

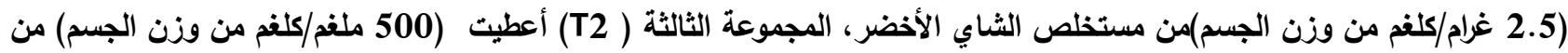

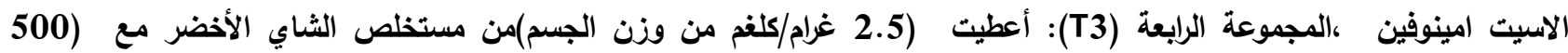
ملغم/كلغم من وزن الجسم) من الاسيت امينوفين .تم قياس انزيمات الكبد في مصل الام خلال الفترات 15 و30 يوم , وفي نهاية

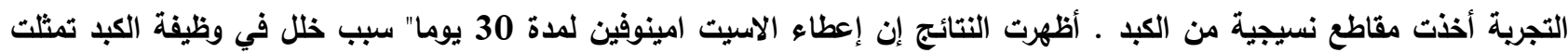
بالزيادة المعنوية ( > 05P ) في مستوى الأنزيمات الناقلة للامين ALT وAST وفعالية أنزيم الفوسفاتيز القاعدي

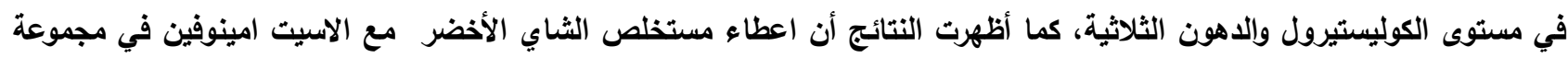

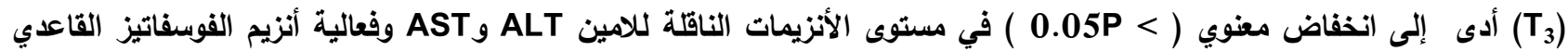

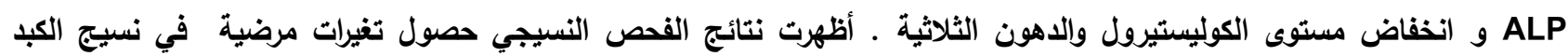
للمجموعة التي أعطيت بالأست امينوفين (T2) وان أعطاء الثاي الاخضر مع الاسيت امينوفين كان فعال في تعديل هذه التغيرات الى فيلى الكلمات المفتاحية : مستخلص الثاي الاخضر، الاسيت امينوفين،ALT,AST,ALP ، الكوليستيرول والدهون الثلاثية. 


\section{INTRODUCTION}

Acetaminophen or Paracetamol is a commonly used as antipyretic (fever reducer) and analgesic (pain reliever), it is usually used for the relieve of pains, headaches and other minor aches and it is a main component in numerous cold and flu therapy. The beginning of analgesia is about 11-29 minutes after oral administration of paracetamol (18). It's halflife is 1- 4 hours, It is usually safe for use at recommended doses (1000 $\mathrm{mg}$ ) per single dose and up to (4000 $\mathrm{mg}$ ) per day for adult (20), acute over dose of paracetamol can cause acute fatal liver damage and rare individuals, a normal dose can do the same $(2,12)$. Green tea is derived from unfermented leaves of Camellia Sinensis plant initially cultivated in east Asia, it is grows as large as a bush or tree. Nowadays Camellia Sinensis grows all over Asia and part of the middle East and Africa. People in Asia countries more ordinarily drink green tea. The healthy properties of green tea are mainly attributed to polyphenols which is chemicals with effective antioxidant properties. Actuality the antioxidant effects of polyphenols are greater than vitamin C (7). The polyphenol also caused in better flavor of green tea (16). Polyphenols in tea are identified as Catechins, Green tea have six main Catechins component (catechins, gallaogatechin, epicatechin, epicatechingallate, and epigallocatechingallate also known as EGCG) which is the most active, in addition green tea contain alkaloids like caffeine, theobromine and theophylline. These alkaloids give green tea effects of stimulant. Also there is an amino acid found in green tea known as L-theamine which has calming effects on the nervous system. Green tea boosts metabolic rates, accelerates fat oxidation and ameliorates insulin sensitivity and glucose tolerance $(19,24)$. The green tea and its extract have been shown to fight obesity and lower LDL-C the two threat factor for cardiac disease and diabetes.( 11,19). The theanin in the green tea might help the body's immune system response when fighting infection by increasing the disease - fighting capacity of gamma delta $\mathrm{T}$ cells (13). The green tea polyphenols can help to prevent the growth of bacteria that cause in bad breath (8), also catechinpolyphenols may be elevate thermogenesis (the production of heat by the body ) and so increases energy expenditure $(1,4)$. The aim of present study was to examine the antioxidant capacity of green tea (CamelliaSinensis) extract (GTE) against acetaminophens induced liver injury in adult male rabbits.

\section{MATRRIALS AND METHODS}

A total number of 40 adult male rabbits (1000$1500 \mathrm{~g}$ ) were used in this experiment. Animals in all stages of the research were housed in irons cages in a conditioned room (22-250) in the animal house of the department of physiology and pharmacology at college of veterinary medicine-university of Baghdad. The animals were kept for ten days for adaptation with the experimental circumstances, Animals had free access to tap water and standard pellet diet all along the experimental time. Randomly the animals were divided into four identical groups (10 rabbits / group) and were treated every day for 30 days as follows : control group (C) : rabbits in this group were permitted to ad libitum provide of drinking water, treated group $\left(\mathrm{T}_{1}\right)$ : rabbits in this group were allowed to drink water containing $2.5 \mathrm{gm} / \mathrm{kg} \mathrm{b} . \mathrm{w}$ (8) of green tea water extract, treated group $\left(\mathrm{T}_{2}\right)$ : rabbits in this group received $500 \mathrm{mg} / \mathrm{kg}$ b.w (1) of acetaminophen orally, treated group $\left(\mathrm{T}_{3}\right)$ : rabbits in this group were allowed to ad libitum supply of drinking water containing $2.5 \mathrm{gm} / \mathrm{kg}$ b.wof tea green extract and received $500 \mathrm{mg} / \mathrm{kg}$ b.w. of Acetaminophen orally. Blood samples were collected at 15 and 30 days of the experiment, blood was collected directly from heart, blood specimens were preserved in tubes and centrifuged at $3500 \mathrm{rpm}$ for 10 minutes, and then serum samples were a liquated and frosted at $-20 \mathrm{c}^{\circ}$ till analysis, serum samples were used to measure the following parameters:- serum aspartate aminotransferase (AST) ,alanin aminotransferase (ALT) , alkaline phosphatase (ALP) cholesterol and triglyceride.by using specialized kits from LINEAR company. For histological studies, rabbits were anesthetized, sacrificed by withdrawal of blood from heart, at once after scarification liver were excised, opened longitudinal and conserved in $10 \%$ neutral formalin buffer solution for preparing of histological sections (15) . 


\section{Preparing of green tea extract( GTE)}

The dry green tea used in this experiment was obtained from local market. The green tea was made by soaking $25 \mathrm{gm}$ of the dry green tea in one litter of boiling tab water for 3-5 minutes, the solution was filtered to make $2.5 \%$ green tea extract and allowed to cool at room temperature (17).

Statistical Analysis Statistical analysis of data was performed using SAS(statistical analysis system-version 9.1). data were subjected to analysis using Two - way analysis of variance (ANOVA). Least significant differences (LSD) post hoc test was used (multiple comparison) to asses significant differences among means. $\quad \mathrm{P}<0.05$ was considered statistically significant (21).

\section{RESULTS AND DISCUSSION}

Table1 illustrated the mean values of alkaline phosphatase ALP (IU/L) in the control group and three treated groups all along the experimental time. After 15 days of treatment a significant $(\mathrm{p}<0.05)$ elevation in ALP was observed in animal received acetaminophen orally $(500 \mathrm{mg} / \mathrm{kg}$ b.w) with mean values of $285.40 \pm 19.74$ as compared to control group( $72.00 \pm 3.74), \quad \mathrm{T}_{1}(70.40 \pm 19.70) \quad$ and $\mathrm{T}_{3}(147.00 \pm 17.72)$. At the same period of the experiment, oral administration of green tea in group $\mathrm{T}_{3}$ caused a significant $(\mathrm{p}<0.05)$ depression in the ALP level $(147.00 \pm 17.72)$ in compared to $\mathrm{T}_{2}$ group $(285.40 \pm 19.74)$. After 30 days of experiment there was also a considerable $(\mathrm{p}<0.05)$ increase in ALP levels in $\mathrm{T}_{2}$ group ( $375.00 \pm 62.57$ ) as compared to control, $\mathrm{T}_{1}$ and $\mathrm{T}_{3}$ groups with mean values of $75.00 \pm 3.53,73.00 \pm 62.57$, and $127.80 \pm 18.42$ respectively.

Table 1. The effect of acetaminophen and green tea on serum alkaline phosphatase ALP (IU/L) in adult male rabbits

\begin{tabular}{|c|c|c|c|c|}
\hline \multirow[t]{2}{*}{ Days } & \multicolumn{4}{|c|}{ Groups } \\
\hline & Control & $\mathbf{T}_{1}$ & $\mathbf{T}_{2}$ & $\mathbf{T}_{3}$ \\
\hline 15 & $\mathrm{C} 72.00 \pm 3.74 \mathrm{a}$ & $\mathrm{C} 70.40 \pm 19.70 \mathrm{a}$ & A285.40 $\pm 19.74 b$ & $\mathrm{~B} 147.00 \pm 17.72 \mathrm{a}$ \\
\hline 30 & C75.00 $\pm 3.53 a$ & C73.00 $\pm 62.57 a$ & $\mathrm{~A} 375.00 \pm 62.57$ & B127.80 $\pm 18.42 b$ \\
\hline
\end{tabular}

Values are expressed as mean $\pm \mathrm{SE}, \mathrm{n}=10 \quad$ Table2 clarified the mean values of serum each group.

$\mathrm{T}_{1}$ : Animals received green tea extract $2.5 \mathrm{gm}$ $/ \mathrm{kg}$ b.w.

$\mathrm{T}_{2}$ : Animals received acetaminophen $500 \mathrm{mg} /$ kg b.w.

$\mathrm{T}_{3}$ : Animals received green tea extract $2.5 \mathrm{gm}$ $/ \mathrm{kg}$ b.w and acetaminophen $500 \mathrm{mg} / \mathrm{kg}$ b.w

Capital different letters in the same row denoted that significant differences among groups $(\mathrm{p}<0.05)$.

Small different letters in the same column denoted that significant differences within groups $(\mathrm{p}<0.05)$.

aspartate aminotransferase (AST) (IU/L) of control and treated groups.A significant $(\mathrm{P}<0.05)$ increase in serum AST was found in group $\mathrm{T}_{2}$ after 15 and 30 days of treatment (114.20 \pm 28.18$),(139.00 \pm 28.27)$ as compared to the values in control, $\mathrm{T}_{1}$ and $\mathrm{T}_{3}$ groups at the same period of time.Oral intake of green tea to $\mathrm{T}_{3}$ group caused further significant $(\mathrm{P}<0.05)$ decline in serum AST along the experiment time $(74.40 \pm 5.18),(66.80 \pm 6.66)$ respectively compared to the values in the other groups.

Table 2. The effect of acetaminophen and green tea on serum aspartate aminotransferase (AST) (IU/L) in adult male rabbits

\begin{tabular}{|c|c|c|c|c|}
\hline \multirow{2}{*}{ Days } & \multicolumn{3}{|c|}{ Groups } & \multirow{3}{*}{$\begin{array}{l}T_{3} \\
\text { B74.40 } \pm \text { 5.18a }\end{array}$} \\
\hline & \multirow{2}{*}{$\begin{array}{l}\text { Control } \\
\text { C50.60 } \pm \text { 5.59a }\end{array}$} & \multirow{2}{*}{$\begin{array}{l}T_{1} \\
C 48.10 \pm 4.15 a\end{array}$} & \multirow{2}{*}{$\begin{array}{l}T_{2} \\
A 14.20 \pm 28.18 b\end{array}$} & \\
\hline 15 & & & & \\
\hline 30 & $\mathrm{C51.00} \pm 3.91 \mathrm{a}$ & $\mathrm{C} 47.23 . \pm 3.20 \mathrm{a}$ & $\mathrm{A} 139.00 \pm 28.27 \mathrm{a}$ & B66.80 $\pm 6.66 \mathrm{~b}$ \\
\hline
\end{tabular}

Values are expressed as mean \pm SE, $\mathrm{n}=10 \quad / \mathrm{kg} \mathrm{b} . \mathrm{w}$ and acetaminophen $500 \mathrm{mg} / \mathrm{kg}$ b.w. each group.

$\mathrm{T}_{1}$ : Animals received green tea extract $2.5 \mathrm{gm}$ $/ \mathrm{kg}$ b.w.

$\mathrm{T}_{2}$ : Animals received acetaminophen $500 \mathrm{mg} /$ kg b.w.

$\mathrm{T}_{3}$ : Animals received green tea extract $2.5 \mathrm{gm}$ Capital different letters in the same row denoted that significant differences among groups $(\mathrm{p}<0.05)$.

Small different letters in the same column denoted that significant differences within groups $(\mathrm{p}<0.05)$. 
Table 3 pointed to the mean values of serum alanin aminotransferase (ALT) (IU/L) or different treated groups. Oral administration of acetaminophen caused significant $(\mathrm{p}<0.05)$ rise in serum alanin aminotransferase (ALT) in $\mathrm{T}_{2}$ group along the experimentalperiod $(120.00 \pm 9.95),(140.80 \pm 14.60)$ as compared

Table 3. The effect of acetaminophen and green tea on serum alanin aminotransferase (ALT) (IU/L) in adult male rabbits

\begin{tabular}{|c|c|c|c|c|}
\hline \multirow[b]{2}{*}{ Days } & \multicolumn{3}{|c|}{ Groups } & \\
\hline & Control & $\overline{T_{1}}$ & $\overline{T_{2}}$ & $\overline{T_{3}}$ \\
\hline 15 & $\mathrm{C} 56.00 \pm 4.11 \mathrm{a}$ & $\mathrm{C} 54.00 \pm 4.10 \mathrm{a}$ & $A 120.00 \pm 9.95 b$ & $\mathrm{~B} 66.60 \pm 8.88 \mathrm{a}$ \\
\hline 30 & $\mathrm{C} 55.20 \pm 2.13 \mathrm{a}$ & $\mathrm{C50.15} \pm \mathbf{3 . 1 5 a}$ & $\mathrm{A} 140.80 \pm 14.60 \mathrm{a}$ & B64.20 $\pm 11.34 \mathrm{a}$ \\
\hline
\end{tabular}

Values are expressed as mean \pm SE, $\mathrm{n}=10 \quad$ Table 4 showed the mean values of serum total each group.

$\mathrm{T}_{1}$ : Animals received green tea extract $2.5 \mathrm{gm}$ $/ \mathrm{kg}$ b.w.

$\mathrm{T}_{2}$ : Animals received acetaminophen $500 \mathrm{mg} /$ kg b.w.

$\mathrm{T}_{3}$ : Animals received green tea extract $2.5 \mathrm{gm}$ $/ \mathrm{kg} \mathrm{b.w}$ and acetaminophen $500 \mathrm{mg} / \mathrm{kg}$ b.w.

Capital different letters in the same row denoted that significant differences among groups $(\mathrm{p}<0.05)$.

Small different letters in the same column denoted that significant differences within groups $(\mathrm{p}<0.05)$.

Table 4.The effect of acetaminophen and green tea on serum total cholesterol (mg/dl) in adult male rabbit

\begin{tabular}{|c|c|c|c|c|}
\hline \multirow[t]{2}{*}{ Days } & \multicolumn{4}{|c|}{ Groups } \\
\hline & Control & $\mathbf{T}_{1}$ & $\mathbf{T}_{2}$ & $\mathbf{T}_{3}$ \\
\hline 15 & $\mathrm{~B} 51.40 \pm 4.80 \mathrm{a}$ & $\mathrm{B50.10} \pm 3.90 \mathrm{a}$ & $A 59.80 \pm 3.24 b$ & B45.40 $\pm 5.44 a$ \\
\hline 30 & $B 49.00 \pm 4.48 a$ & $\mathrm{BC} 45.30 \pm 2.65 \mathrm{a}$ & $A 80.20 \pm 5.15 a$ & $\mathrm{C} 41.40 \pm 4.90 \mathrm{a}$ \\
\hline
\end{tabular}

Values are expressed as mean $\pm \mathrm{SE}, \mathrm{n}=10$ Table5 indicated to the mean values of serum each group.

$\mathrm{T}_{1}$ : Animals received green tea extract $2.5 \mathrm{gm}$ /kg b.w.

$\mathrm{T}_{2}$ : Animals received acetaminophen $500 \mathrm{mg} /$ kg b.w.

$\mathrm{T}_{3}$ : Animals received green tea extract $2.5 \mathrm{gm}$ $/ \mathrm{kg}$ b.w and acetaminophen $500 \mathrm{mg} / \mathrm{kg}$ b.w.

Capital different letters in the same row denoted that significant differences among groups $(\mathrm{p}<0.05)$.

Small different letters in the same column denoted that significant differences within groups $(\mathrm{p}<0.05)$. cholesterol $(\mathrm{mg} / \mathrm{dl})$ in the control $, \mathrm{T}_{1}, \mathrm{~T}_{2}$ and $\mathrm{T}_{3}$ groups.After 15 and 30 days of treatment the results of animals who received acetaminophen orally $\left(\mathrm{T}_{2}\right)$ showed significant $(\mathrm{p}<0.05)$ increase in serum total cholesterol (59.80 \pm 3.24$),(80.20 \pm 5.15)$ in compared to other groups .after 30 days of experiment, the results of animal group who take green tea and acetaminophen $\left(\mathrm{T}_{3}\right)$ showed a major $(\mathrm{p}<0.05)$ reduce in serum total cholesterol ( 41.40 $\pm 4.90)$ comparing to control, $\mathrm{T}_{1}$ and $\mathrm{T}_{2}$ groups $(49.00 \pm 4.48),(45.30 \pm 2.65),(80.20 \pm 5.15)$. triglyceride $(\mathrm{mg} / \mathrm{dl})$ of control and other experiment groups. During the experimental time 15 and 30 days there was a significant $(\mathrm{p}<0.05)$ rise in serum triglyceride noticed in $\mathrm{T}_{2}$ group $(106.00 \pm 12.97)$, $(128.00$ $\pm 27.15)$ in compared to control, $\mathrm{T}_{1}$ and $\mathrm{T}_{3}$ groups. Oral administration of green tea with acetaminophen $\left(\mathrm{T}_{3}\right.$ group) for more than fifteen days caused a significant $(\mathrm{p}<0.05)$ elevation in serum triglyceride with mean values of $61.60 \pm 6.18$ in compared to control, $\mathrm{T}_{1}$ and $\mathrm{T}_{2} \quad(54.40 \pm 5.60), \quad(49.50 \pm 4.12)$, (128.00 \pm 27.15$)$. 
Table 5. The effect of acetaminophen and green tea on serum triglyceride (mg/dl) in adult male rabbit

\begin{tabular}{|c|cccc|}
\hline \multirow{2}{*}{ Days } & \multicolumn{4}{|c|}{ Groups } \\
\cline { 3 - 5 } & Control & $\mathbf{T}_{1}$ & $\mathbf{T}_{2}$ & $\mathbf{T}_{3}$ \\
\cline { 2 - 5 } 15 & $\mathbf{B 5 5 . 8 0} \pm \mathbf{3 . 0 2 a}$ & $\mathbf{B C 5 2 . 3 0} \pm \mathbf{3 . 4 0 a}$ & $\mathbf{A 1 0 6 . 0 0} \pm \mathbf{1 2 . 9 7 b}$ & $\mathbf{B 6 5 . 0 0} \pm 7.67 \mathrm{a}$ \\
30 & $\mathrm{C54.40} \pm \mathbf{5 . 6 0 a}$ & $\mathrm{C49.50} \pm \mathbf{4 . 1 2 a}$ & $\mathbf{A 1 2 8 . 0 0} \pm \mathbf{2 7 . 1 5 a}$ & $\mathbf{B 6 1 . 6 0} \pm \mathbf{6 . 1 8 a}$ \\
\hline
\end{tabular}

Values are expressed as mean $\pm \mathrm{SE}, \mathrm{n}=10$ remained enzyme molecules on the cell each group.

$\mathrm{T}_{1}$ : Animals received green tea extract $2.5 \mathrm{gm}$ / kg b.w.

$\mathrm{T}_{2}$ : Animals received acetaminophen $500 \mathrm{mg} /$ kg b.w.

$\mathrm{T}_{3}$ : Animals received green tea extract $2.5 \mathrm{gm}$ / kg b.w and acetaminophen $500 \mathrm{mg} / \mathrm{kg}$ b.w.

Capital different letters in the same row denoted that significant differences among groups $(\mathrm{p}<0.05)$.

Small different letters in the same column denoted that significant differences within groups $(\mathrm{p}<0.05)$.

The current experiment illustrate that acetaminophen caused considerable increase( $\mathrm{p}<0.05$ ) in level of liver enzymes (ALP, ALT, and AST), serum cholesterol and triglyceride levels as compared to $C, T_{1}$ and $T_{3}$ groups. this rise was changed significantly $(\mathrm{P}<0.05)$ in the group which taken up the green tea and acetaminophen to a semi normal values. The role of paracetamol in causing hepatic injury is taking an important consideration, since Liver plays an essential function in organizing many of metabolic actions and making of different essential materials in the body. liver function enzymes (AST, ALT, and ALP) showed improve in activities after administration of acetaminophen for long period of time. The damage in the liver caused by acetaminophen associated with the fact that little amount of acetaminophen are turned into toxic metabolites. This toxic metabolites combine with liver proteins and result in cellular damage. The quantity of toxic metabolite formed and the capability of the liver to eliminate this metabolite before it joins to liver protein effect the degree of liver injury (14). There is a significant $(\mathrm{P}<0.05)$ increase in the efficacy of plasma alkaline phosphatase (ALP) following an acute sever injury to the hepatic tissues which is existing in the lining membrane of the hepatocytes which has a cell membrane location related with the canalicular membrane injure (6). The raise in the alkaline phosphatase activity is maybe a reflexion of membrane fragment emitted to the plasma as a result of liver damage. The elevated values of both AST and ALT enzymes might be attributed to the damage in the hepatocellular membrane possibly as a result of engaged of toxic metabolite of paracetamol with the protein and lipid components of the liver membrane (22). Treatment with green tea formed a significant $(\mathrm{P}<0.05)$ decline in the levels of serum AST, ALT and ALP as compared to acetaminophen treated group. These decrease point to the capability of green tea for stabilizing plasma membrane in addition to repair the hepatic tissue injuries occurred by oxidative stress. This consequence is acceptable with the ordinarily conventional opinion in which serum levels of transaminase go back to normal with regeneration of hepatocytes as well as curing of hepatic parenchyma (5). Alkaline phosphatase (ALP) is an enzyme localize within the bile ducts and utilize as index for estimation of hepatic excretory work, the serum activity of this enzyme is highly elevated in certain liver damage $(7,23)$. The aptitude of green tea for lowering the serum activity of ALP proposes the steadiness of the biliary dysfunction in rabbits liver through injury prompted by acetaminophen $(3,25)$. moreover green tea caused a significant $(\mathrm{P}<0.05)$ incline of serum triglyceride and cholesterol compared to paracetamol treated group. The diminution of serum cholesterol possibly because of the suppression of the absorption of cholesterol in the intestin by green tea leading to minimize the serum cholesterol concentration (9). The reduction in the triglyceride observed in recent study may be due to the fact that green tea restrains postprandial hypertriacylglycerolemia through the suppression of pancreatic lipase and subsequently delayed the absorption of fat (10). The histological sections of liver in the control group showed normal appearance (Fiqure-1 ), while there is a vacuolar degeneration and proliferation of kupffer cells and few RBCs in the sinusoids in 
acetaminophen and green tea group( Fiqure2 ), also there is sever necrosis in the liver parenchyma and infiltration of inflammatory cells around the portal area. There is also dilation of the central vein with focal aggregation of MNCS in liver parenchyma in acetaminophen group(Fiqure-3 ). There is a hydropic degeneration in the green tea group (Fiqure-4).

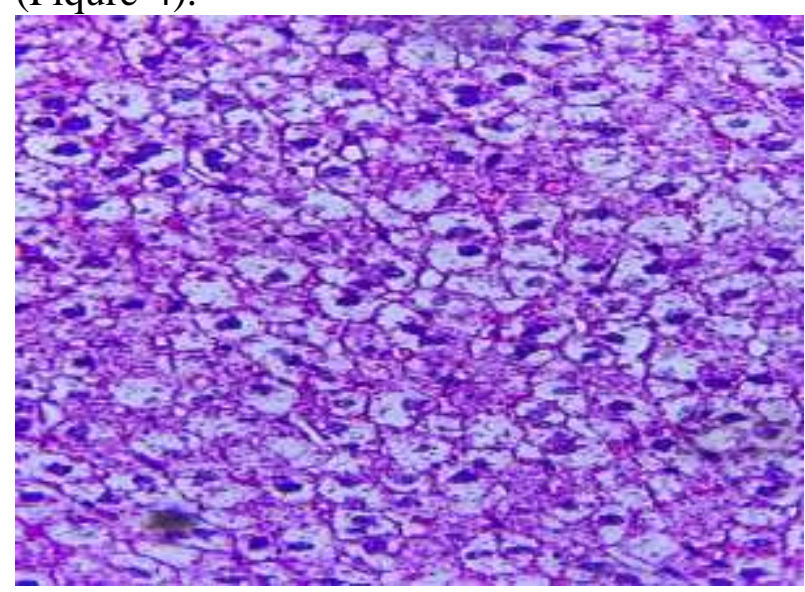

Figure1.Histological section in the liver of rabbit from control group (X400,H\&E stain)

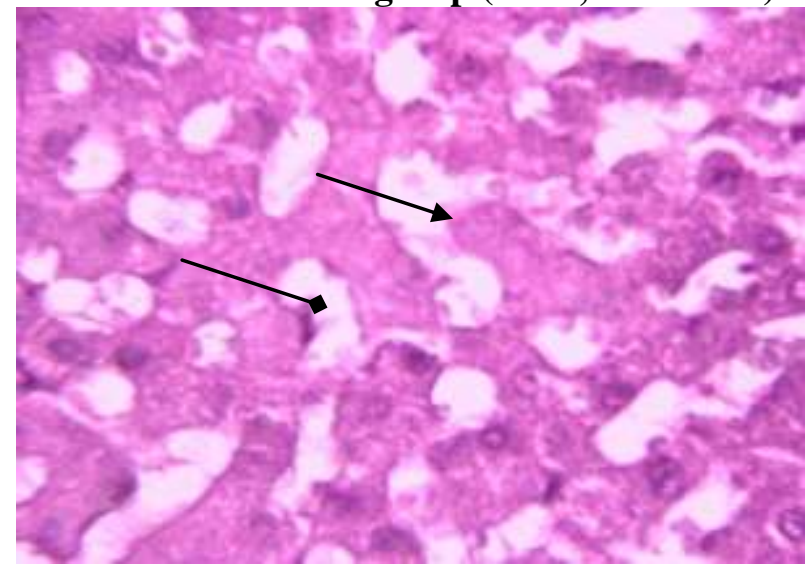

Figure2 . Histological section in the liver of rabbit From green tea and acetaminophen group, there is a proliferation of kupffer cells $(\longrightarrow$ ) and few RBCs in

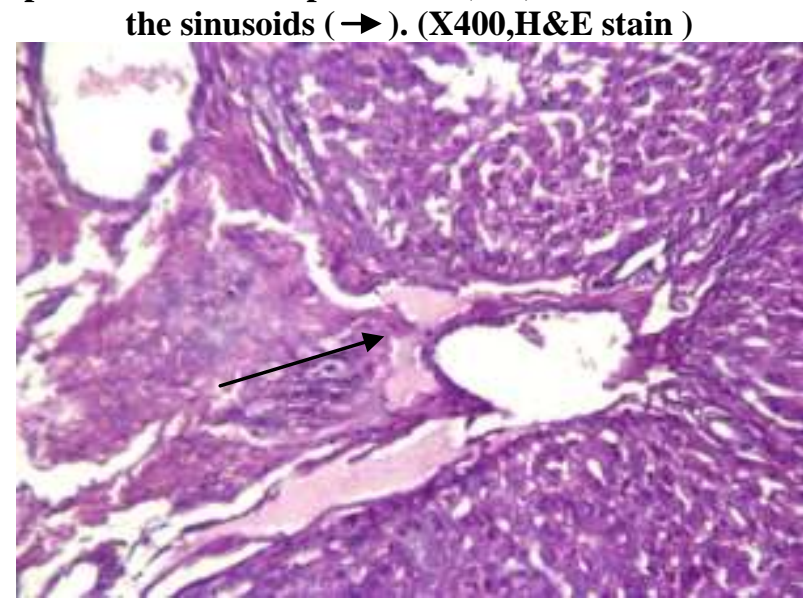

Figure 3. Histological section in the liver of rabbit from acetaminophen group, There is sever necrosis $($ ) in the liver parenchyma.. (X400,H\&E stain )

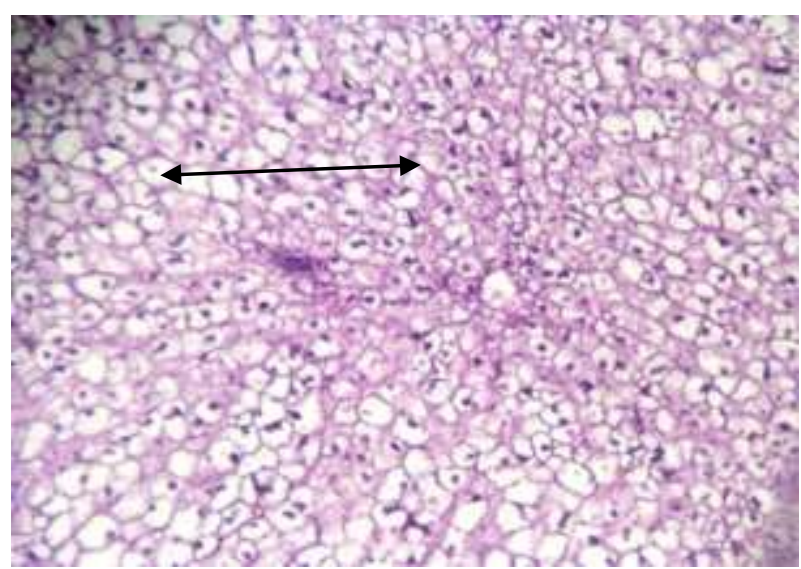

Figure 4.Histological section in the liver of rabbit From green tea group, there is a hydropic degeneration $(\longleftrightarrow$. X400,H\&E stain)

\section{REFERANCES}

1.Belza, A., S. Toubro, and A. Astrup.2009. The effect of caffeine, green tea and tyrosine on thermogenesis and energy intake. Eur $\mathrm{J}$ ClinNutr.63(1):57-64.

2.Bower, W.A., M. Johns, H.S. Margolis, I.T.Williams and B.Bell. 2007. Population based surveillance for acute liver failure Am.J.gastroenterol ; 102: 2459-63.

3. David, C., and D. M. Twedt. 2001. Liver diseases: Lecture notes. Academic Veterinary Medicine Inc.: 1-10.

4.Dullooa, A. G., C. Duret, and D. Rohrer.1999. Efficacy of agreen tea extract rich in catechin polyphenol and caffeine iccreasing 24-h energy expenditure and fat oxidation in human .Am.J.Clin.Nut. 70(6):1040-5.

5. Frei, B and J. V. Higdon.2003. Antioxidant activity of tea polyphenols in vivo: the underlying mechanisms.; evidence from animal studies. J. Nutr. Proc. Soc. Exp.Biol.Med.133(10):3275-3284.

6.Hewawasam, R. P., K. A. Jayatilaka, C.Pathirana, and L. K. Mudduwa. 2003. Protective effect of Asteracanthalongifoliaextracts mouse liver injury induced by carbon tetrachloride and paracetamol. Pharmacy and Pharmacol.55(10): 1413-1418. 7.Higdon J. V. 2003. Tea catechins and polyphenols: health ffects,metabolism and antioxidant function. Crit.Rev. Food Sci.Nutr. 43:89-143.

8.Hirasawa, M., K. Takada, M.Makimura, and S. Otake. 2002. Improvement of periodontal status by green tea catechin usinga local 
deliver system: A clinical study. J. Periodontal. Res.37: 433-438.

9.Ikeda I. 2008.Multifunctional effects of green tea catechins on prevention of the metabolic syndrome.Asia Pac J ClinNutr;17 (S1):273-274.

10.Ikeda I., K. Tsuda, Y. Suzuki, M. Kobayashi, T. Unno, H. Tomoyori, H. Goto, Y. Kawata,K. Imaizumi, A. Nozawa, and T. Kakuda. 2005. Tea catechins with a galloyl moiety suppress postprandial hypertriacylglycerolemia by delaying lymphatic transport of dietary fat in rats. J Nutr.,135:155-159.

11.Iso, H. C. Date, K. Wakai, M. Fukui, and A. Tamakoshi.2006. The relationship between green tea and total caffeine intake and risk for self -reported type 2 diabetes among Japanese adult. 144(8):554-562.

12.Khashab, M., A. J. Toctor, and P. Y. Kwopy.2007 . Epidemiology of acute liver failure. CurrGastroenterolRep.9(1):66-73.

13.Lal, G., N. Zhang, T. W. Vander, Y. Ding, W. Ju, E. P. Bottinger, S. P. Reid, D. E. Levy, and J. S. Bromberg.2009. Epigenetic regulation ofFoxp3 expressioninregulatory Tcell by DNA methylation. J. Immunol. 182(1):259-73.399.

14. Larson, A.M., J. Polson, and R. J. Fontana. 2005. Acetaminophen-induced acute liver failure: results of a United States multicenter, prospective study. Hepatology.42 (6): 136472.

15. Lee,G. and L. G. Luna. 1968. Manual of histological staining methods of armed Forces Iinstitutes of pathology. $3^{\text {rd }}$ ed. MC Grow-Hill book company . New York. Pp: 12-31.

16.Lu, H., X. F. Meng, M. J. Lee, C. Li, P. Maliakal, and C. S. Yang. 2003. Bioavailability and biological activity of tea polyphenols. Food factors in health promotion and disease prevention symposium. Series851 :9-5.
17.Maity, S., J. Vadasiromoni, and D. Ganguly.1998. Role ofglutathione in the antiulcer effect of hot water extract of black tea. Jpn. J. Pharmacol. 78: 285-292.

18. Moller, P., S. Sindet-Pedersen, G. Juhi, A. Dillenschneider, and L. Skoglund.2005.Onset of acetaminophen analgesia:Comparsion of oral and intravenous routes after third molar surgery British journal of anaesthesia. 94(5):642-648.

19.Nagao T., T. Hase, and I. Tokimitsu.2007. A green tea extract high in catechins reduces body fat and cardiovascular risks in humans. Obesity (Silver Spring).15(6):1473-83.

20.Perrott, D.A.,T.Piira,B.Goodenough and G.D. Champion. 2004. Efficacy and safty of acetaminophen vs ibuprofen for treating children's pain or fever: a meta-analysis. Arch PediatrAdolesc Med.158 (6): 521-6.

21.SAS.2010. SAS/start user Guide for personal computer. Release 9.1, SAS. Institute, Inc., Cary,N.C.,USA.

22.Shenoy, A. K., S. N. Somayaji, K. L. and Bairy.2001. Hepatoprotectiveeffects of ginkgo bilobaagainst carbon tetrachloride induced Hepatic injury in rats. Ind $\mathbf{J}$ Pharamcol. 33:260-266.

23.Skrzydlewsja, E.,A. Augustyniak, J. Ostrowska,W. Luczaj, and E. Tarasiuk.2002. Green tea protection against aging-induced oxidativestress. Free Radic. Biol Med. 555557.

24.Venablees, M. C.,C. J. Hulston, H. R.Cox, and A. E.Jeukendrwp.2008.Green tea extract ingestion, fat oxidation , and glucose tolerance in healthy human Am.J.Clin. Nut.87(3) : 77884.

25.ZhangQ.,A. P. Kelly, L. WangL,S. W. French, X. Tang,H. S. Duong,D. V.Messadi, and A. D. Le.2006. Green tea extract and (-)epigallocatechin-3-gallate inhibit mast cellstimulated type I collagen expression in fibroblasts. J. Invest.Dermatol.126(12):7-13. 